\title{
UJI BERBAGAI DOSIS PUPUK HERBAFARM GRANUL TERHADAP PERTUMBUHAN DAN PRODUKSI \\ TANAMAN PADI SAWAH (Oryza sativa L.) DENGAN METODE SRI
}

\author{
AHMAD EFRIZAL ${ }^{1)}$, CHAIRIL EZWARD ${ }^{2)}$, SEPRIDO ${ }^{2)}$ \\ ${ }^{1,2,2}$ Program Studi Agroteknologi Fakultas Pertanian \\ Universitas Islam Kuantan Singingi, Teluk Kuantan 2017 \\ Jl. Gatot Subroto KM 7 Jake Tlpn. 081268855945 \\ Email.ezwardchairil@yahoo.com
}

\begin{abstract}
ABSTRAK
Penelitian ini bertujuan untuk mengetahui respons berbagai dosis herbafarm granul terhadap pertumbuhan dan produksi tanaman padi sawah (Oryza Sativa L.) dengan metode SRI (System Of Rice Intensification). Rancangan digunakan adalah Rancangan Acak Kelompok (RAK) Non Faktorial yaitu Pupuk Herbafarm Granul terdiri dari 6 taraf perlakuan terdiri dari 3 ulangan H0 (tanpa perlakuan), H1 (2,43 gram / plot), H2 (4,86 gram / plot), H3 (7,29 gram / plot), H4 (9,72 gram / plot), H5 (12,15 gram / plot). Masing-masing perlakuan di ulang sebanyak 3 kali, sehingga diperoleh 18 unit percobaan/plot, setiap plot terdapat 9 tanaman dan 7 diantaranya tanaman sampel. Jumlah tanaman keseluruhan 162 tanaman Kemudian data-data yang diperoleh di analisis secara statistik, dengan UJi Lanjut Beda Nyata Jujur (BNJ), pada taraf $5 \%$. Berdasarkan hasil penelitian maka dapat disimpulkan bahwa perlakuan pupuk herbafarm granul denagan metode SRI memberikan pengaruh nyata terhadap parameter pengamatan, untuk pengamatan umur berbunga (77.33 hst) dan umur panen $(109.33 \mathrm{hst})$ perlakuan terbaik terdapat pada perlakuan H1, sedangkan untuk pengamatan jumlah anakan produktif (39.90 batang) dan berat gabah kering ( 87.48 gram) perlakuan terbaik terdapat pada perlakuan $\mathrm{H} 4$.
\end{abstract}

Kata kunci : Padi sawah, Herbafarm granul, Metode SRI

\begin{abstract}
This report aims to understand response various herbafarm granule doses of growth and the production of rice (Oryza Sativa L.) fields with the SRI (System Of Rice Intensification). Draft use is a random (group shelves) non factorials namely fertilizer herbafarm granule consisting of 6 standard treatment consisting of 3 test, $\mathrm{HO}$ (Without treatment), $\mathrm{H1}$ (2,43 g/plot), H2 (4,86 g/plot), H3 (7,29 g/plot), H4 (9,72 g/plot), H5 (12,15 g/plot). Each treatment repeat three times, 18 units in order to obtain a plot / experiment, Every a plot there were 9 plants and 7 of them sample plants. The quantity of a crop a whole 162 plant. Then the data obtained by in statistically analysis, further by test different real bnj truthful, 5 percent the first. Based on the research done so it can be concluded that treatment fertilizer herbafarm granule with the SRI give impact on the real parameters, for observation age flowering ( $77.33 \mathrm{hst}$ ) and aged harvest ( 109.33 hst ) treatment is the best $\mathrm{H} 1$ treatment, As for the number of productive saplings (39.90 stem) and heavy of dried grain ( 87.48 gram) treatment is the best $\mathrm{H} 4$ treatment.
\end{abstract}


Keywords : rice fields, herbafarm granule, the method of SRI

Diterima: 17 September 2018, disetujui 17 Desember 2018

\section{PENDAHULUAN}

Beras masih menjadi bahan pangan pokok di Indonesia, hal ini disebabkan oleh kandungan gizi dari padi yang dapat memenuhi kebutuhan gizi yang dibutuhkan oleh tubuh manusia, seperti Karbohidrat , protein, lemak, dan serat dalam jumlah yang cukup (Purwono dan Heni, 2009).

Indonesia sampai saat ini masih mengimpor beras dari Cina dan Thailand. Provinsi Riau dan Kabupaten Kuantan Singingi, produksi padi juga belum mampu memenuhi kebutuhan, hal ini dapat kita lihat dari data BPS Propinsi Riau (2012) data tanaman pangan meliputi luas panen tanaman padi, selama periode 2011 luas panen tanaman padi mengalami penurunan sebesar $7,47 \%$ yaitu dari 156.088 ha menjadi 145.242 ha.

Kabupaten Kuantan Singingi, tingkat produksi padi masih rendah. Produksi padi di Kabupaten Kuantan Singingi dari tahun 2009 sampai dengan 2012 mengalami fluktuasi, dimana pada tahun 2009 produksi tanaman padi hanya 26.232,04 ton sedangkan untuk kebutuhan beras $36.583,50$ ton. Sehinnga harus mendatangkan beras dari daerah lain sebanyak 10.352,04 ton. Pada tahun 2010 produksi tanaman padi mencapai 44.132,63 ton tetapi masih belum bisa mencukupi kubutuhan, yang mana kebutuhan beras pada tahun 2010 sebanyak 46.264,91 ton. Pada tahun 2011 produksi tanaman padi menurun $43.460,74$ ton, sedangkan pada tahun 2012 produksi tanaman padi mencapai $47.408,63$ ton (Dinas Tanaman Pangan Kabupaten Kuantan Singingi, 2012). Rendahnya produksi padi di daerah ini disebabkan teknik budidaya yang digunakan masih tradisional, dan teknik pemeliharaan tanaman yang tidak memenuhi standar.

Salah satu metode peningkatan produksi yaitu dengan metode intensifikasi, beberapa cara dalam metode ini adalah dengan pemberian pupuk dengan takaran yang tepat, menggunakan varietas yang unggul, merubah pola tanam yang hanya satu kali satu tahun menjadi dua sampai tiga kali dalam satu tahun, mengoptimalkan saluran irigasi dan aplikasi teknik budidaya yang popular digunakan yaitu dengan menggunakan Sistem intensifikasi Padi yang dikenal dengan System of Rice Intensification (SRI). System ini dapat meningkatkan produksi padi 50\%-100\% (Mutakin, 2005).

Sistem SRI yang diaplikasikan pada tanah yang tidak subur dapat menhasilkan 8 ton ha $^{-1}$ sampai 20 ton hektar ${ }^{-1}$, bila dibandingkan produksi padi pada lokasi yang sama tanpa menggunakan teknik budidaya SRI, hanya menghasilkan 2 ton hektar ${ }^{-1}$ (Barkelaar, 2001).

Bahan organik merupakan salah satu komponen yang harus ditambahkan dalam budidaya SRI. Pupuk organic berperan memperbaiki kondisi fisi, kimia, dan biologi tanah. Menurut Murbandono (2000) pupuk organic yang baik mengandung Carbon yang tinggi. Pupuk Herbafarm Granul merupakan salah satu pupuk organic yang memenuhi persyaratan tersebut, selain mengandung mikroorganisme, Herbafarm granul juga mengandung unsur hara makro dan mikro yang dibutuhkan oleh tanaman (PT. Sido Muncul, 2010). Tujuan penelitian ini adalah untuk mendapatkan dosis pupuk Herbafarm yang tepat dalam 
meningkatkan produksi padi dengan teknik budidaya SRI.

\section{METODOLOGI PENELITIAN}

\section{Tempat dan Waktu}

Penelitian ini telah dilaksanakan di lahan sawah Desa Petapahan Kecamatan Gunung Toar Kabupaten Kuantan Singingi. Waktu penelitian dimulai pada akhir bulan November 2014 sampai Maret 2015.

\section{Bahan dan Alat}

Bahan yang digunakan dalam penelitian adalah padi Varietas Cisokan, pupuk Bio Organik (Herbafarm Granul), kompos, papan, plastik hitam, paku, cat dan bahan-bahan lain yang mendukung penelitian ini. Sedangkan alat-alat yang digunakan dalam penelitian adalah cangkul, sabit, timbangan, meteran, ember, tali plastik, gergaji, kamera dan alat-alat lain yang mendukung penelitian ini.

\section{Metode Penelitian}

Rancangan yang digunakan dalam penelitian ini adalah Rancangan Acak
Kelompok (RAK) Non Faktorial yaitu Pupuk Herbafam Granul $(\mathrm{H})$ yang terdiri dari 6 taraf perlakuan, masing-masimg perlakuan di ulang sebanyak 3 kali, jadi diperoleh 18 plot, setiap plot terdapat 9 tanaman dan 7 diantaranya dijadikan tanaman sampel. Jumlah tanaman keseluruhan 162 tanaman. Rancangan perlakuan yaitu Pupuk Bio Organik Herbafarm Granul $(\mathrm{H})$ sebagai berikut : $\mathrm{H} 0$ = tanpa pemberian Pupuk Bio Organik Herbafarm Granul (control); H1= $30 \mathrm{~kg}$ ha $^{-1}$ setara dengan 2,43 gram plot $^{-1} ; \mathrm{H} 2=$ $60 \mathrm{~kg} \mathrm{ha}^{-1}$ setara dengan 4,86 gram plot $^{-1} ; \mathrm{H} 3=90 \mathrm{~kg} \mathrm{ha}^{-1}$ setara dengan 7,29 gram plot $^{-1} ; \mathrm{H} 4=120 \mathrm{~kg} \mathrm{ha}^{-1}$ setara dengan 9,72 gram plot $^{-1}$; dan H5 $=150$ $\mathrm{kg} \mathrm{Ha}{ }^{-1}$ setara dengan 12,15 gram plot ${ }^{-1}$.

Peubah yang diamati adalah tinggi tanaman (cm), umur berbunga (hari), umur panen (hari), jumlah anakan produktif rumpun $^{-1}$, dan berat gabah kering $(\mathrm{g})$.

\section{HASIL DAN PEMBAHASAN}

\section{Tinggi Tanaman $(\mathbf{c m})$}

Data hasil pengamatan terhadap pupuk herbafarm granul dengan metode parameter tinggi tanaman setelah SRI berpengaruh tidak nyata terhadap dianalisis secara statistik sidik ragam tinggi tanaman padi, Tabel 1. menunjukkan bahwa perlakuan pemberian

Tabel 1. Rerata tinggi tanaman padi sawah (O. sativa L.) umur 70 HST dengan perlakuan berbagai dosis herbafarm granul dengan metode SRI.

\begin{tabular}{cc}
\hline Faktor $($ H) HerbaFarm Granul & Rerata \\
\hline H0 (tanpa perlakuan) & 95.74 \\
H1 (2,43 gram plot $\left.{ }^{-1}\right)$ & 101.60 \\
H2 (4,86 gram plot $\left.{ }^{-1}\right)$ & 97.60 \\
H3 (7,29 gram plot $\left.^{-1}\right)$ & 99.01 \\
H4 (9,72 gram plot $\left.^{-1}\right)$ & 99.16 \\
H5 (12,15gram plot & 97.60 \\
\hline
\end{tabular}


Berdasarkan Tabel 1 diatas hasil penelitian telah sesuai dengan deskripsi tinggi tanaman varietas Cisokan yaitu berkisar $90-100 \mathrm{~cm}$, sedangkan pada semua perlakuan dari hasil penelitian menunjukkan tinggi tanaman yaitu berkisar antara $95.7 \mathrm{~cm} \mathrm{(H0)}-101 \mathrm{~cm}$ (H1). Perlakuan yang menunjukkan tertinggi untuk tinggi tanaman padi sawah yaitu terdapat pada perlakuan $\mathrm{H} 1$ dengan dosis 2,43 gram plot $^{-1}$, hal ini disebabkan oleh sesuainya dosis pupuk herbafarm granul yang diberikan, jika dibandingkan dengan perlakuan pupuk herbafarm granul $\mathrm{H} 2, \mathrm{H} 3, \mathrm{H} 4$ dan H5. Pada perlakuan H0 tanpa pemberian pupuk herbafarm granul, tinggi tanaman paling rendah, diduga karena pada $\mathrm{HO}$ ini unsur haranya belum tercukupi untuk tanaman. Selain unsur hara yang cukup factor yang mempengaruhi pertumbuhan tanaman adalah faktor genetik hal ini didukung oleh Habibie et al, ( 2011) yang menyatakan bahwa "pertumbuhan ialah proses perubahan yang terjadi dalam kehidupan tanaman, pertumbuhan ditandai dengan pertambahan organ tanaman yang tidak bisa kembali (irreversible)". pertumbuhan tersebut dapat diketahui dari perubahan penampilan pada tanaman, dan lingkungan, dimana lingkungan yang baik adalah lingkungan yang mampu menyediakan segala kebutuhan tanaman, meliputi unsur hara, air, cahaya, udara dan tempat tumbuh.

Tidak terlihatnya perbedaan tinggi tanaman dari masing-masing perlakuan pupuk herbafarm granul ini disebabkan karena kebutuhan nutrisi pada saat perumbuhan vegetatif belum terserap oleh tanaman secara sempurna. Fenomena ini sesuai dengan penelitian yang dilakukan oleh Dubeldes (2015) terhadap tanaman mentimun yang juga menggunakan pupuk herbafarm granul, juga tidak berpengaruh nyata terhadap tinggi tanaman.

\section{Umur Berbunga (Hari)}

Hasil sidik ragam menunjukkan bahwa perlakuan herbafarm granul dengan metode SRI memberikan pengaruh nyata terhadap umur muncul bunga. Hasil uji lanjut pada taraf 5\% dapat dilihat pada Tabel 2.

Umur muncul bunga tercepat terlihat pada perlakuan $\mathrm{H} 1$ yaitu 77,33 HST dan umur muncul bunga yang lebih lama terlihat pada perlakuan $\mathrm{H} 0$ yaitu 83,00 HST. Dengan tercepatnya umur perlakuan $\mathrm{H} 1$ ini dikarenakan pemberian pupuk herbafarm granul yang sesuai dan cukup untuk proses pembungaan. Beberapa unsur hara yang mendukung untuk perkembangan tanaman adalah unsur hara $\mathrm{N}, \mathrm{P}$ dan $\mathrm{K}$, pada pupuk herbafarm granul menurut PT. Sido Muncul (2010) mengandung $\mathrm{N}$ sebanyak $(2,39 \%), \mathrm{P}(2,31 \%)$ dan $\mathrm{K}(2,52 \%)$. Unsur $\mathrm{N}$ yang tersedia akan membantu dalam mempercepat munculnya bunga, sehingga dapat dimanfaatkan oleh tanaman. Hal ini sesuai dengan pendapat Surtinah (2017) bahwa unsur $\mathrm{N}$ sangat berperan dalam membentuk klorofil, sehingga dengan intensitas cahaya yang cukup maka proses fotosintesis akan optimal, sehingga fotosintat yang dihasilkan juga akan optimum.

Menurut Susilawati (2012) "umur berbunga pada tanaman tidak hanya dipengaruhi oleh faktor eksternal saja, akan tetapi juga dipengaruhi oleh faktor internal dari tanaman itu sendiri, pembungaan merupakan fenomena fisiologi yang tidak sederhana dimana perubahan fase vegetatif menjadi fase generatif merupakan perubahan yang sangat besar Karena struktur jaringannya berbeda sekali".

\section{Umur Panen (Hari)}

Hasil sidik ragam menunjukkan bahwa perlakuan pemberian pupuk herbafarm granul dengan metode SRI berpengaruh nyata terhadap umur panen 
padi sawah. Hasil uji lanjut BNJ pada taraf 5\% dapat dilihat pada Tabel 3.

Tabel 2. Rerata umur berbunga padi sawah (O. sativa L.) $_{\text {. }}$ dengan perlakuan berbagai dosis herbafarm granul dengan metode SRI.

\begin{tabular}{cc}
\hline Faktor $($ H) HerbaFarm Granul & Rerata \\
\hline \hline H0 (tanpa perlakuan) & $83.00 \mathrm{~b}$ \\
H1 $\left(2,43\right.$ gram plot $\left.^{-1}\right)$ & $77.33 \mathrm{a}$ \\
H2 $\left(4,86\right.$ gram plot $\left.^{-1}\right)$ & $82.67 \mathrm{ab}$ \\
H3 $\left(7,29\right.$ gram plot $\left.^{-1}\right)$ & $81.33 \mathrm{ab}$ \\
H4 $\left(9,72\right.$ gram plot $\left.^{-1}\right)$ & $79.33 \mathrm{ab}$ \\
H5 $\left(12,15\right.$ gram plot $\left.^{-1}\right)$ & $81.67 \mathrm{ab}$ \\
\hline KK $=\mathbf{1 1 . 0 7 \%}$ & BNJ H $=\mathbf{5 . 3 7}$
\end{tabular}

Angka-angka pada kolom dan baris yang diikuti oleh huruf kecil yang sama menunjukkan tidak berbeda nyata menurut BNJ pada taraf $5 \%$.

Tabel 3. Rerata umur panen padi sawah $(O$. sativa L.) dengan perlakuan berbagai dosis herbafarm granul dengan metode SRI.

\begin{tabular}{cc}
\hline Faktor $(\mathbf{H})$ HerbaFarm Granul & Rerata \\
\hline \hline H0 (tanpa perlakuan) & $121.67 \mathrm{~b}$ \\
H1 $\left(2,43\right.$ gram plot $\left.^{-1}\right)$ & $109.33 \mathrm{a}$ \\
H2 (4,86 gram plot & $118.00 \mathrm{ab}$ \\
H3 (7,29 gram plot & -1 \\
H4 $\left(9,72\right.$ gram plot $\left.^{-1}\right)$ & $112.67 \mathrm{ab}$ \\
H5 (12,15gram plot & $111.33 \mathrm{ab}$ \\
\hline KK $=\mathbf{1 1 . 1 9 \%}$ & $118.33 \mathrm{ab}$ \\
\hline
\end{tabular}

Angka-angka pada kolom dan baris yang diikuti oleh huruf kecil yang sama menunjukkan tidak berbeda nyata menurut BNJ pada taraf $5 \%$.

Umur panen tercepat ditemukan pada perlakuan $\mathrm{H} 1$ (dosis $2,43 \mathrm{~g} \mathrm{plot}^{-1}$ ) yaitu 109 HST, dan umur panen terlama ditemukan pada perlakuan H0 ( tanpa pemberian pupuk herbafarm granul) yaitu 121 HST. Cepatnya panen pada perlakuan H1 dibandingkan dengan perlakuan lainnya $(\mathrm{H} 0, \mathrm{H} 2, \mathrm{H} 3, \mathrm{H} 4$ dan $\mathrm{H} 5)$, fenomena ini menunjukkan bahwa pemberian dosis pupuk herbafarm granul sudah sesuai dengan kebutuhan tanaman. Menurut PT Sido Muncul (2010) herbafarm granul mengandung asam humat, asam fulfat, asam amino bioprotectan, hormon tanaman, Unique Growth Factor (UGF), unsur hara makromikro dan mikrobia tanah. Untuk hormon tanaman terdiri dari dari auksin, giberrelin, sitokinin dan cholchicine. Sedangkan Unique Growth Factor (UGF) adalah faktor pemacu tanaman yang sangat berperan dalam pertumbuhan tanaman, dari dua hal tersebut sehingga dapat mempercepat umur panen padi sawah. Hasil penelitian yang dilakukan oleh Jimmy (2008) bahwa hormon tanaman dengan kandungan giberrelin dapat mempercepat pembungaan dan pembentukan biji tanaman sehingga tanaman dapat mengahasilkan lebih cepat dari umur tanaman yang tidak menggunakan hormon tanaman unggul.

Berdasarkan deskripsi umur panen varietas Cisokan yaitu antara umur 110120 HST, hanya perlakuan H1 yang umur panennya dapat lebih cepat yaitu 109 HST, sedangkan perlakuan H0 mengalami keterlambatan dari deskripsi dalam proses pemanenan yaitu $121 \mathrm{HST}$, dan perlakuan 
$\mathrm{H} 2$, H3, H4 dan H5 sesuai dengan deskripsi umur panen varietas Cisokan

Keterlambatan masa panen perlakuan H0, disebabkan karena umur muncul bunga pada perlakuan $\mathrm{H} 0$ juga lebih lambat dibandingkan perlakuan yang lainnya. Penyebab perlakuan H0 berbeda dari perlakuan yang lainya juga dikarenakan perlakuan H0 tanpa pemberian pupuk herbafarm granul. Sehingga ketersediaan unsur hara untuk proses pertumbuhan dan perkembangan tanaman tidak mencukupi, sehingga tanaman tidak berkembang dengan optimal.

\section{Jumlah Anakan Produktif rumpun ${ }^{-1}$}

Setelah dianalisis secara statistik dari hasil sidik ragam menunjukkan bahwa perlakuan pemberian pupuk herbafarm granul dengan metode SRI berpengaruh nyata terhadap jumlah anakan produktif. Hasil uji lanjut pada taraf 5\% dapat dilihat pada Tabel 4.

Tabel 4. Rerata jumlah anakan produktif padi sawah (O. sativa L.) dengan perlakuan berbagai dosis herbafarm granul dengan metode SRI.

\begin{tabular}{|c|c|}
\hline Faktor (H) HerbaFarm Granul & Rerata \\
\hline H0 (tanpa perlakuan) & $31.33 \mathrm{~b}$ \\
\hline H1 $\left(2,43\right.$ gram plot $\left.^{-1}\right)$ & $31.19 \mathrm{~b}$ \\
\hline $\mathrm{H} 2\left(4,86\right.$ gram plot $\left.^{-1}\right)$ & $33.57 \mathrm{~b}$ \\
\hline H3 $\left(7,29\right.$ gram plot $\left.^{-1}\right)$ & $35.00 \mathrm{ab}$ \\
\hline H4 (9,72 gram plot $\left.^{-1}\right)$ & $39.90 \mathrm{a}$ \\
\hline H5 $\left(12,15\right.$ gram plot $\left.^{-1}\right)$ & $32.67 \mathrm{~b}$ \\
\hline $\mathrm{KK}=6.01 \%$ & BNJ H $=5.78$ \\
\hline
\end{tabular}

Angka-angka pada kolom dan baris yang diikuti oleh huruf kecil yang sama menunjukkan tidak berbeda nyata menurut BNJ pada taraf $5 \%$.

Dari Tabel 4 menunjukkan bahwa perlakuan herbafarm granul dengan metode SRI berpengaruh nyata terhadap jumlah anakan produktif, dimana perlakuan yang menunjukkan rerata tertinggi yaitu 39.90 batang pada perlakuan $\mathrm{H} 4$ dengan dosis 9,72 gram plot ${ }^{-}$ 1 . Rata-rata jumlah anakan produktif tertinggi dari berbagai penggunaan dosis pupuk herbafarm granul dengan metode SRI terdapat pada perlakuan H4 (dosis 9,72 gram/plot) dengan jumlah 39,90 batang, dan terendah terdapat pada perlakuan $\mathrm{H} 1$ (dosis 2,43 gram/plot) dengan jumlah anakan 31.19 batang. Semua perlakuan memberikan hasil yang melebihi dari deskripsi jumlah anakan padi sawah varietas cisokan, yang mana berdasarkan deskripsi menunjukkan bahwa jumlah anakan produktif 20-25 batang. Hal ini dipengaruhi oleh cocok nya varietas cisokan terhadap lingkungan tempat penelitian dan juga varietas cisokan merupakan varietas unggul.

Tingginya jumlah anakan produktif pada perlakuan $\mathrm{H} 4$ ini disebabkan karena kebutuhan unsur hara untuk tanaman tercukupi. Menurut Rizqiani et al, (2007) "Tanaman membutuhkan unsur hara untuk melakukan proses-proses metabolisme, terutama pada fase vegetatif. Unsur-unsur hara yang terserap dapat digunakan tanaman untuk mendorong pembelahan sel dan pembentukan sel-sel baru guna untuk membentuk organ tanaman seperti daun, anakan, dan akar yang lebih baik sehingga dapat memperlancar proses fotosintesis". Berpengaruh nya perlakuan $\mathrm{H} 4$ tidak terlepas dari peranan pemberian pupuk herbafarm granul dan juga penggunaan metode SRI.

Pupuk herbafarm granul mempunyai sifat slow release. Maka pada perlakuan $\mathrm{H} 4$ dapat mencukupi sampai masa 
produksi. Taylor (2002) menyatakan bahwa "keuntungan dari sifat slow release yaitu pelepasan unsur hara secara lambat dengan volume pelepasan mendekati kapasitas akar tanaman dalam penyerapan unsur hara tetapi berlangsung dalam waktu yang lama sehingga mengurangi unsur hara ke lingkungan". Metode SRI membantu tanaman dalam menyerap unsur hara secukupnya, hal ini sesuai dengan pendapat Suiatna (2008) bahwa pada "pengelolaan SRI (System of Rice Intensification) faktor pencucian tersebut telah diminimalisir yaitu dengan penggenangan air secara macak-macak (tinggi air $<2-3 \mathrm{~cm}$ ) yang dilakukan secara periodic". Jadi tanaman dapat meyerap unsur hara secukupnya.

Menurut Purwasasmita dan Sutaryat (2014) "secara keseluruhan metode SRI memberikan hasil lebih baik, dalam arti lebih produktif (tanaman lebih tinggi, anakan lebih banyak, malai lebih panjang dan bulir lebih berat), lebih sehat (tanaman lebih tahan hama dan penyakit), lebih kuat (tanaman lebih segar, lebih tahan kekeringan), lebih menguntungkan (biaya produksi lebih rendah)". Hal ini juga sejalan dengan pendapat Nainggolan et al, (2014) "pengelolaan padi dengan metode SRI ini bertujuan untuk mencapai produksi tinggi melalui peningkatan anakan dan jumlah anakan produktif, peningkatan panjang malai, dan peningkatan berat gabah padi, serta memperbaiki perkembangan akar tanaman sehingga pertumbuhannya sehat dan produksi meningkat. Untuk mencapai tujuan tersebut, diperlukan persyaratan diantaranya tanam bibit muda yang berumur kurang dari 15 hari setelah semai. Lalu menanam bibit dengan satu lubang satu bibit dimana jarak tanam lebih lebar sekitar $25 \mathrm{~cm}$, kemudian dilakukan pindah sesegera mungkin dan akar tanaman dijaga agar tidak putus, ditanam dangkal antara 1 $-2 \mathrm{~cm}$ dan akar tidak ditekuk, lalu air diatur sampai macak-macak serta penyiangan dilakukuan seawal mungkin".

Rendahnya jumlah anakan produkif pada perlakuan $\mathrm{H} 0, \mathrm{H} 1$, dan $\mathrm{H} 2$ ini disebabkan tidak tercukupi kebutuhan unsur hara bagi tanaman, Sutedjo (2008) mengatakan pertumbuhan tanaman memerlukan unsur hara yang cukup banyak sehingga pemberian pupuk diperlukan agar tanaman dapat tumbuh dengan baik, apabila kekurangan unsur hara akan mengakibatkan pertumbuhan terhambat sehingga produksi yang dihasilkan tidak maksimal.

Sanusi (2014) pada penelitiannya juga menggunakan metode SRI dengan pupuk kandang jumlah anakan produktif terhadap varietas batang piaman hanya15,89 batang, varietas IR-42 14,89 batang dan varietas inpari 12 sebanyak 13,33 batang. Sedangkan pada penelitian ini jumlah anakan produktif terhadap varietas cisokan dengan pemberian pupuk herbafarm granul dengan metode SRI menghasilkan jumlah anakan sebanyak 39.90 batang, jadi penggunaan pupuk herbafarm granul dengan metode SRI lebih efektif dalam meningkatkan jumlah anakan produktif padi sawah. Jika dibandingkan dengan cara kovensional dari hasil penelitian Susilawati (2012) menggunakan varietas ciherang dengan pemberian hormon tanaman unggul menghasilkan jumlah anakan produktif sebanyak 18,32 batang.

\section{Berat Gabah Kering (Gram)}

Setelah dianalis secara statistik dari hasil sidik ragam menunjukkan bahwa perlakuan pemberian pupuk herbafarm granul dengan metode SRI berpengaruh nyata terhadap berat gabah kering padi sawah. Hasil uji lanjut pada taraf 5\% dapat dilihat pada Tabel 5. 
Tabel 5. Rerata berat gabah kering padi sawah ( $O$. sativa $L_{\text {.) }}$ dengan perlakuan berbagai dosis herbafarm granul dengan metode SRI.

\begin{tabular}{cc}
\hline Faktor (H) HerbaFarm Granul & Rerata \\
\hline \hline H0 (tanpa perlakuan) & $62.43 \mathrm{~b}$ \\
H1 (2,43 gram / plot) & $68.52 \mathrm{ab}$ \\
H2 (4,86 gram / plot) & $71.05 \mathrm{ab}$ \\
H3 (7,29 gram / plot) & $68.86 \mathrm{ab}$ \\
H4 (9,72 gram / plot) & $87.48 \mathrm{a}$ \\
H5 (12,15gram / plot) & $75.14 \mathrm{ab}$ \\
\hline
\end{tabular}

KK $=11.07 \%$

BNJ $\mathbf{H}=22.68$

Angka-angka pada kolom dan baris yang diikuti oleh huruf kecil yang sama menunjukkan tidak berbeda nyata menurut BNJ pada taraf 5\%.

Berat gabah kering padi sawah tertinggi dari berbagai pemberian dosis pupuk herbafarm granul dengan metode SRI terdapat pada perlakuan $\mathrm{H} 4$ (dosis 9,72 gram/plot) dengan berat 87.48 gram, tingginya hasil panen pada perlakuan $\mathrm{H} 4$ tidak terlepas dari jumlah anakan yang dihasilkan sebanyak (39.90 batang) dan terendah pada perlakuan HO (tanpa pemberian pupuk herbafarm granul) dengan berat 62.43 gram. Hal ini disebabkan kerana pupuk herbafarm granul dengan metode SRI yang lebih efektif dalam meningkatkan hasil panen, dan juga dipengaruhi oleh jumlah anakan produktif, secara umum jumlah anakan yang banyak sangat dipengaruhi oleh jarak tanam. Dalam penelitian ini jarak tanam yang digunakan adalah $30 \mathrm{~cm}$ x $30 \mathrm{~cm}$ jarak yang terbaik dalam metode SRI. Hal ini sesuai dengan pendapat Rokhmania (2010) yang menyatakan bahwa kerapatan populasi tanaman dalam satuan luas tertentu mempengaruhi pertumbuhan dan hasil tanaman padi.

Tingginya hasil panen juga tidak terlepas dari peranan penggunaan varietas unggul. Penggunaan varietas unggul diantaranya tahan terhadap hama dan penyakit, daya tumbuh tinggi serta menghasilkan produksi yang tinggi sehingga dapat menguntungkan bagi petani. disamping penggunaan varietas unggul, hasil produksi juga sangat dipengaruhi keseimbangan bahan organik dengan ketersedian unsur hara akan berpengaruh positif terhadap bobot gabah kering padi. Hal ini sesuai dengan pendapat Sukamto (2007) pengunaan bahan organik akan memperbaiki tekstur dan kadar liat tanah sehingga $\mathrm{P}$ dalam tanah dapat tersedia. Penambahan bahan organik akan memperbaiki aerase dan drainase tanah menjadi lebih baik. Dengan lengkapnya unsur hara yang terkandung dalam pupuk herbafarm granul yaitu N, P dan K. Maka akan mempengaruhi pertumbuhan dan produksi tanaman hal ini sama dengan hasil penelitian yang dilakukan Surtinah (2015) pada tanaman jagung manis bahwa ketersediaan N,P, dan $\mathrm{K}$ yang cukup dan tersedia bagi tanaman dapat meningkatkan berat tongkol berkelobot jagung manis melebihi deskripsinya.

Pada penelitian ini hasil panen setiap perlakuan pupuk herbafarm granul menunjukkan fluktuatif (naik turun). Perlakuan yang tertinggi untuk berat gabah kering yaitu perlakuan H4. Karena pada perlakuan $\mathrm{H} 4$ merupakan dosis yang tepat untuk tanaman padi sawah menggunakan metode SRI dengan dosis 9,72 gram/plot. Sedangkan dari penelitian Dubeldes (2015) rata-rata berat buah tanaman mentimun dari 5 perlakuan pupuk herbafarm granul yaitu $\mathrm{H} 1, \mathrm{H} 2, \mathrm{H} 3, \mathrm{H} 4$ dan H5 memberikan hasil yang meningkat, hasil tersebut membuktikan bahwa pupuk organik hebafarm granul berperan sangat penting dalam memperbaiki kesuburan 
tanah sehingga dapat meningkatkan produksi tanaman mentimun.

Hasil panen yang tertinggi yaitu perlakuan $\mathrm{H} 4 \quad(87.48$ gram) bila di konversikan ke ton $\mathrm{ha}^{-1}$, maka hasil panen varietas cisokan memperoleh hasil \pm 9.7 ton $\mathrm{ha}^{-1}$, jika dilihat dari deskripsi varietas cisokan potensi hasil yaitu 6,0 ton, jadi dari hasil penelitian ini dengan pemberian pupuk herbafarm granul dengan metode

\section{KESIMPULAN DAN SARAN \\ Kesimpulan}

Penggunaan pupuk herbafarm granul dengan metode SRI terhadap varietas cisokan memberikan pengaruh yang nyata terhadap umur berbunga, umur panen, jumlah anakan produktif dan berat gabah kering. Perlakuan terbaik untuk umur berbunga $(77,33$ HST) dan umur panen (109.33 HST) terdapat pada perlakuan H1 (dosis 2,43 $\mathrm{g} \mathrm{plot}^{-1}$ ), sedangkan jumlah anakan produktif (39.90 batang) dan berat gabah kering (87.48 gram.) pada perlakuan H4 (dosis 9,72 gram plot $^{-1}$ ).

\section{Saran}

Teknik budidaya tanaman padi sawah yang intensif dapat dilakukan,

\section{DAFTAR PUSTAKA}

Badan Pusat Statistik. 2012. Pertanian Tanaman Pangan_Badan Pusat Statistik (BPS). Riau.

Barkelaar, D. 2001. EDN Stories: SRI, The System of Rice Intensification: Less Can be More.http://www.echonet.org.

Diakses : 18 November 2009.

Dinas Tanaman Pangan Kabupaten Kuantan Singingi. 2012. Laporan Tahunan Produksi Padi.

Dubeldes. 2015. Respons Penggunaan Berbagai Dosis Herbafarm Granul terhadap Pertumbuhan dan Produksi Tanaman Mentimun (Cucumis sativa
SRI dapat melebihi dari deskripsi potensi hasil dari varietas cisokan yaitu naiknya \pm 3.7 ton $\mathrm{ha}^{-1}$. Sedangkan hasil panen perlakuan yang terendah yaitu perlakuan H0 (62.43 gram) dikonversikan ke ton ha ${ }^{1}$, maka memperoleh hasil \pm 6.9 ton $\mathrm{ha}^{-1}$, hasil ini masih melebihi dari deskripsi potensi hasil varietas cisokan yaitu 0,9 ton/ha.

dengan memperhatikan aspek-aspek pendukung dalam meningkatkan hasil produksi, dalam memperoleh hasil produksi yang optimal tentu memerlukan pemupukan, perawatan, dan juga mengunakan kultur teknis dalam budidaya padi sawah salah satunya menggunakan metode SRI. Setelah melakukan penelitian penulis menyarankan untuk budidaya tanaman padi sawah mengunakan pupuk herbafarm granul dengan metode SRI dengan dosis $120 \mathrm{~kg} / \mathrm{ha}$ memberikan hasil produksi yang tinggi. Untuk mendapatkan pertumbuhan dan produksi yang lebih baik lagi hendaknya penambahan pupuk kimia dalam jumlah sedikit.

L.) di Polibag. Skripsi . FP UNIKS. Teluk Kuantan. [Unpublished]

Habibie ,AF. Nugroho dan Suryanto A. 2011. Kajian Pengaturan Jarak Tanam dan Irigasi Berselang (Intermittentirrigation) pada Metode Sri (System Of Rice Intensification) terhadap Produktivitas Tanaman Padi (Oryza Sativa L.) Varietas Ciherang. Diakses http:// www.google.com Pada tanggal 22/04/2015.

Jimmy, 2008. Pupuk Hantu. Mutiata Keraton. Bogor. 
Murbandono. 2000. Manfaat bahan Organik Bagi Tanaman. Puslit Biologi. LIPI. Bogor.

Mutakin, J. 2005. Kehilangan Hasil Padi Sawah Akibat Kompetisi Gulma pada Kondisi SRI (Systen of Rice Intencification). Tesis. Pascasarjana. Unpad Bandung

Nainggolan, K. Harahap, IM dan Erdiman. 2014. Teknologi Melipatgandakan Produksi Padi Nasional. Gramedia Pustaka Utama. Jakarta.

PT Sido Muncul. 2010. Herbafarm Bio Organik Fertilizer. Semarang.

Purwono. Ms dan Heni,P. 2009. Budidaya Delapan Jenis Tanaman Pangan Unggul. Penebar Swadaya. Jakarta.

Rizqiani, F.N., et.al. 2007. "Pengaruh Dosis dan Frekuensi Pemberian Pupuk Organik Cair Terhadap Pertumbuhan dan Hasil Buncis (Phaseolus vulgaris L.) pada Dataran Rendah". Jurnal Ilmu Tanah dan Lingkungan, Vol. 7 No. 1. :42-53.

Rokhmania, Fani, Y. Sugito dan Suryanto, A. 2010. Kajian Pola Tanam Pada Produktivitas Tanaman Padi Sawah (Oryza sativa L.) Varietas Ciherang. Skripsi. FP_UB. Malang.

Sanusi, A. 2014. Pengaruh Berbagai Varietas dan Pupuk Kandang Terhadap Pertumbuhan dan Produksi Padi Sawah Dengan Metode SRI. Skripsi. FP UNIKS. Teluk Kuantan.
Sukamto. 2007. Teknologi Unggulan Tanaman Pangan. Badan Penelitian dan Pengembangan Teknologi. Bogor. 82 hal.

Susilawati. 2012. Uji Berbagai Varietas dan Pemberian Hormon Tanaman Unggul (HANTU) terhadap Pertumbuhan dan Produksi Padi Sawah (Oryza sativa L.). Skripsi. FP UNIKS. Teluk Kuantan.

Sutaryat, A. 2008. System Pengelolaan Pertanian ramah Lingkungan dengan Metode System of Rice Intensification (SRI). http://www. Jabarprov.go.id. Diakses tanggal 2203-2013.

Sutedjo, M. M. 2008. Pupuk dan Cara Pemupukan. Rineka Cipta. Jakarta.

Surtinah, S. 2015. Pengujian Tiga Varietas Jagung Manis (Zea mays saccharata) Di Rumbai Kota Pekanbaru. Jurnal Ilmiah Pertanian, 12(1), 37-43.

Surtinah, S. 2017. Potensi Hasil Jagung Manis (Zea Mays Saccharata, Sturt) Dengan Pemberian Paket Teknologi Pupuk Dan Zat Pengatur Tumbuh. Jurnal BiBieT, 2(1), 37-44.

Taylor, C. 2002. Logistik dalam Pengolahan Pupuk : Penyediaan, Penggudangan, Aplikasi, dan Monitoring. Makalah Dipresentasikan dalam Seminar Pengelolaan pada Kelapa Sawit. PT. Sentana Adidaya Pratama. 1 Maret 2002 Medan. 